\title{
PENGGUNAAN FILM DOKUMENTER SEBAGAI SUMBER BELAJAR DALAM PROSES PEMBELAJARAN IPS SEJARAH DI SMP KETAPANG
}

\author{
Juwarsi Sukraningsih \\ Guru IPS SMPN 3 Ketapang \\ Email: juwarsi_sukraningsih68@gmail.com
}

\begin{abstract}
Abstrak
Penelitian ini fokusnya adalah Penggunaan Film Dokumenter sebagai Sumber Belajar pada Proses Pembelajaran Sejarah di SMP Negeri 5 Magelang, antara lain adalah, (1) Keefektifitasan penggunaannya, (2) Kondisi Sarana dan Prasarana penunjang, (3) Tanggapan dan Apresiasi Guru, (4) Kendala dan Upaya dalam mengatasi masalah yang timbul dari penggunaan Film Dokumenter pada Pembelajaran Sejarah. Tujuan dari penelitian ini adalah untuk mengetahui (1) Keefektifitasan penggunaannya, (2) Kondisi Sarana dan Prasarana penunjang, (3) Tanggapan dan Apresiasi Guru, (4) Kendala dan Upaya dalam mengatasi masalah. Penelitian ini dilaksanakan pada bulan September s.d. November 2019. Film dokumenter sendiri dapat digunakan sebagai salah satu sumber belajar mata pelajaran IPS yang dapat membawa dampak positif dalam proses pembelajaran yang dapat menumbuhkan motivasi belajar siswa. Selain untuk menumbuhkan motivasi belajar siswa, penggunaan film documenter juga diharapkan untuk memudahkan siswa dalam memahami materi yang disampaikan oleh guru. Penggunaan film dokumenter dalam kegiatan pembelajaran IPS juga menuntut guru untuk mencari film-film documenter yang menarik dan sesuai dengan materi agar tujuan pembelajaran dapat tercapai.
\end{abstract}

\section{Kata Kunci : Film Dokumenter, Sumber Belajar, Pembelajaran Sejarah.}

\section{PENDAHULUAN}

Pendidikan adalah usaha sadar dan sistematis yang dilakukan oleh orang-orang yang diserahi tanggung jawab untuk mempengaruhi peserta didik agar mempunyai sifat dan tabiat sesuai dengan citacita pendidikan. Pendidikan aalah bantuan yang diberikan dengan sengaja kepada peserta didik dalam pertumbuhan jasmani maupun rohaninya untuk mencapai tingkat dewasa (Munib, 2010:34). Tujuan pendidikan adalah membentuk sumber daya manusia yang berkualitas dan mampu berkompetisi dalam menghadapi tantangan global zaman, dalam mencapai tujuan ini para penyelenggara pendidikan harus pula memikirkan apa yang harus dilakukan agar tujuan pendidikan dapat terselenggara dengan baik agar tujuan pendidikan dapat tercapai.

Pendidikan yang baik harus disertai dengan pengajar yang baik, sumber belajar yang baik dan juga peserta didik yang baik pula agar tujuan pembelajaran dapat tercapai. SMP Negeri 3 Ketapang sendiri merupakan salah satu sekolah yang sudah mampu melaksanakan proses pembelajaran dengan baik. Hal ini peneliti katakan karena peneliti merupakan salah satu guru disekolah tersebut. Dari apa yang peneliti alami selama mengajar di SMP Negeri 3 Ketapang, peneliti dapat memanfaatkan dengan baik sumber belajar yang dimiliki. Program belajar yang direncanakan pun sangat baik. Di SMP Negeri 3 Ketapang sendiri memanfaatkan berbagai macam sumber-sumber belajar yang ada, bukan hanya terpaku hanya dari buku ajar saja. Salah satu contoh sumber belajar yang dipakai adalah film dokumenter.

Pembelajaran yang berkualitas sangat tergantung dari motivasi pelajar dan kreatifitas pengajar. Seorang pelajar yang memiliki motivasi tinggi ditunjang dengan pengajar yang mampu memfasilitasi motivasi tersebut akan membawa pada keberhasilan pencapaian target belajar. Target belajar dapat diukur melalui perubahan sikap dan kemampuan siswa melalui proses belajar. Desain pembelajaran yang baik, ditunjang fasilitas yang memandai, ditambah dengan kreatifitas guru akan membuat peserta didik lebih mudah mencapai target belajar.

Kita ketahui bahwa untuk mengaktifkan siswa dalam mengikuti pembelajaran haruslah menggunakan metode-metode yang tepat dan sumber belajar yang menarik, sehingga suasana pembelajaran menjadi baik dan siswa dapat dengan fokus mengikuti pembelajaran. Pembelajaran sejarah yang dikenal membosankan haruslah ditempuh dengan berbagai cara agar pembelajaran menjadi mengasyikan dan menyenangkan. Iklim kelas merupakan salah satu indikator penting yang berpengaruh terhadap kualitas pembelajaran, 
disamping faktor-faktor pendukung lainnya (Aman, 2011:119). Penggunaan film dokumenter adalah salah satu terobosan agar siswa tidak bosan dalam belajar. Siswa akan cenderung lebih semangat dan refresh sebelum pembelajaran sejarah dimulai.

SMP Negeri 3 Ketapang merupakan salah satu sekolah yang cukup diperhitungkan di Kabupaten Ketapang yang didirikan dengan harapan mampu menyelenggarakan pendidikan berstandar global, dan mampu bersaing didunia global. Fasilitas yang memadai dan lingkungan sekolah yang strategis membuat pembelajaran di SMP Negeri 3 Ketapang berjalan dengan baik dan lancar. Akan tetapi persepsi siswa tentang pembelajaran sejarah di SMP Negeri 3 Ketapang saat ini juga masih ada yang berpifikir membosankan. Oleh karena itu, guru pun menggunakan film dokumenter sebagai salah satu sumber belajar agar siswa menjadi semangat dan lebih aktif dalam pembelajaran sejarah.

Perlunya memadukan antara teknologi dan pendidikan mendorong adanya berbagai kreativitas yang muncul sebagai motivasi dan paradigma untuk melaksanakan pendidikan yang tidak monoton dan mempunyai daya serap materi yang tinggi. Melalui media audio visual membuat peserta didik semakin bersemangat untuk mempelajari dan memahami sejarah. Dengan hal demikian maka guru pengampu mata pelajaran sejarah menggunakan film dokumenter untuk meningkatkan semangat siswa untuk mempelajari sejarah. Dengan menggunakan film tersebut diharapakan siswa mampu memahami dan mampu menganalisis tiap permasalahan yang akan diteliti.

Berdasarkan latar belakang diatas, maka penulis merasa tertarik untuk meneliti Penggunaan film dokumenter sebagai sumber belajar dalam proses pembelajaran ips sejarah di smp negeri 3 ketapang. Tujuan dari penelitian ini adalah sebagai berikut untuk mengetahui ke-efektifitasan pembuatan film documenter sebagai sarana siswa untuk mempelajari Sejarah, untuk mengetahui kondisi sarana dan prasarana dalam menunjang dan mendukung penggunaan film dokumenter pada pembelajaran Sejarah, untuk mengetahui tanggapan guru dan siswa dalam penggunaan film documenter, dan untuk mengetahui kendala kendala yang dihadapi dalam penggunaan film dokumenter dan upaya untuk mengatasinya.

Sumber belajar dapat diartikan sebagai informasi yang disajikan dan disimpan dalam berbagai bentuk media, yang dapat membantu siswa dalam belajar sebagai perwujudan dari kurikulum. Bentuknya tidak terbatas apakah dalam bentuk cetakan, video, format perangkat lunak atau kombinasi dari berbagai format yang dapat digunakan oleh siswa maupun guru (Isjoni, 2007:109)

Pada dasarnya sumber belajar dapat memberikan informasi kepada guru dan siswa dalam proses pembelajaran. Sumber belajar yang disajikan secara menarik dapat pula menimbulkan rasa ingin tahu kepada siswa. Jadi apapun benda yang digunakan baik berupa data, cetakan/buku, film dokumenter, video, orang, yang hakikatnya dapat mempermudah proses pembelajaran itu merupakan sumber belajar serta penggunaan berbagai sumber belajar dapat memberikan rangsangan kepada siswa untuk belajar dan dapat mempercepat pemahaman serta penguasaan pada bidang keilmuan tertentu.

Film dokumenter adalah film yang mendokumentasikan kenyataan. Istilah "dokumenter" pertama digunakan dalam resensi film Moana (1926) oleh Robert Flaherty, ditulis oleh The Moviegoer, nama samaran John Grierson, di New York Sun pada tanggal 8 Februari 1926.

Film Dokumenter sering dianggap sebagai rekaman dari _aktualitas ‘_ potongan rekaman sewaktu kejadian sebenarnya berlangsung, saat orang yang terlibat di dalamnya berbicara, kehidupan nyata seperti apa adanya, spontan, dan tanpa media perantara. Walaupun kadang menjadi bahan ramuan utama dalam pembuatan dokumenter, unsur-unsur itu jarang menjadi bagian dari keseluruhan film dokumenter itu sendiri, karena semua bahan tersebut harus diatur, diolah kembali, dan ditata struktur penyajiannya. Terkadang, bahkan dalam pengambilan gambar sebelumnya, berbagai pilihan harus diambil oleh para pembuat film dokumenter untuk menentukan sudut pandang, ukuran shot (type of shot), pencahayaan, dan lain-lain, agar dapat mencapai hasil akhir yang mereka inginkan.

Pengertian film dokumenter secara umum adalah rekaman kejadian atau peristiwa dalam bentuk audio visual yang tercipta tanpa ada unsur rekayasa. Film dokumenter dapat dibuat oleh perorangan, kelompok/organisasi, atau institusi pemerintah dan swasta dengan berdasarkan maksud dan tujuan yang diinginkan. Beberapa proses yang harus dilakukan dalam pembuatan film dokumenter adalah pra produksi, produksi dan pasca produksi. Hal terpenting dalam proses produksi adalah riset, karena dokumenter membutuhkan data-data yang valid untuk dituangkan dalam bentuk audio visual.

Pembelajaran adalah suatu sistem atau proses membelajarkan subjek didik atau pembelajran yang direcanakan atau didesain, dilaksanakan atau dievaluasi secara sistematis agar subjek didik atau pembelajar dapat mencapai tujuan-tujuan pembelajaran secara efektif dan 
efisien. Sejarah adalah suatu ilmu pengetahuan yang mempelajari segala peristiwa atau kejadian yang telah terjadi pada masa lampau dalam kehidupan umat manusia.

Pengajaran sejarah bertujuan agar siswa menyadari adanya keragaman pengalaman hidup pada masing-masing masyarakat dan adanya cara pandang yang berbeda terhadap masa lampau untuk pemahaman untuk menghadapi masa yang akan datang (Depdiknas, 2003, dalam Isjoni 2007 : 72).

Melalui pengajaran di sekolah, siswa mampu mengembangkan kompetensi untuk berfikir secara kronologis dan memiliki pengetahuan tentang masa lampau yang dapat digunakan untuk memahami dan menjelaskan proses perkembangan dan perubahan masyarakat serta keragaman sosial budaya dalam rangka menemukan dan menumbuhkan jati diri bangsa di tengah-tengah kehidupan masyarakat dunia

Pemilihan materi dan pengembangan tujuan pembelajaran sejarah yang tidak dapat hanya dipandang sebagai rutinitas. Di samping memerlukan pemahaman mengenai hakikat belajar sejarah dan wawasan mengenai nilai edukatif sejarah dalam kaitan dengan kehidupan masa kini dan masa yang akan datang, juga memerlukan kesungguhan dan ketekunan untuk melaksanakannya. Masalah ini menjadi semakin penting apabila seorang pengajar sejarah hendak mengembangkan atau melaksanakan strategi atau pendekatan baru dalam pembelajarannya, seperti halnya pendekatan garis besar kronologis dengan pendekatan tematis (Abdullah dalam Aman, 2011: 99).

Pembelajaran sejarah, selain bertugas memberikan pengetahuan sejarah (kognitif), tetapi juga untuk memperkenalkan nilai-nilai luhur bangsanya (afektif). Kedua hal ini tidak akan memiliki arti bagi kehidupan peserta didik pada masa sekarang dan pada masa yang akan datang apabila peserta didik tidak mampu memahami maknanya. Mengingat setiap peserta didik memiliki kemampuan yang tidak sama untuk menangkap makna yang ada di balik cerita sejarah, maka pengajar sejarah seyogianya selalu menekankan pada arti dan makna dari semua peristiwa yang

dipelajarinya.

Sarana pembelajaran merupakan segala sesuatu yang memudahkan terlaksananya kegiatan pembelajaran. Sarana pembelajaran meliputi ruang belajar, media pembelajaran, dan sumber belajar. Pemanfaatan media pembelajaran secara optimal dapat mempertinggi kualitas proses belajar mengajar yang pada gilirannya dapat meningkatkan kualitas hasil belajar siswa. Sarana pembelajaran juga berpengaruh pada kinerja mengajar guru dalam meningkatkan kualitas pembelajaran. Sarana pembelajaran yang baik untuk meningkatkan kualitas pembelajaran meliputi ruang kelas yang memadai atau representatif, lengkap dan memadainya media pembelajaran, serta ketersediaan sumber-sumber belajar yang mendukung. Sarana pembelajaran secara umum dimaknai sebagai segala sesuatu yang mendukung kegiatan proses pembelajaran (Aman, 2011: 119).

Sejarah merupakan cabang ilmu pengetahuan yang menelaah tentang asal usul dan perkembangan serta peranan masyarakat di masa lampau berdasarkan metode dan metodologi tertentu. Pengetahuan masa lampau tersebut mengandung nilai-nilai kearifan yang dapat digunakan untuk melatih kecerdasan, membentuk sikap, watak dan kepribadian peserta didik. Mata pelajaran sejarah memiliki arti strategis dalam pembentukan watak dan peradaban bangsa yang bermartabat serta dalam pembentukan manusia Indonesia yang memiliki rasa kebangsaan dan cinta tanah air (Aman, 2011: 56).

\section{METODE PENELITIAN}

Metode penelitian yang digunakan dalam penelitian penggunaan film dokumenter sebagai sumber belajar dalam proses pembelajaran IPS Sejarah di SMP Negeri 3 Ketapang adalah metode kualitatif. Menurut David Williams (1995) dalam Moleong (2011 : 5) mengatakan bahwa penelitian kualitatif adalah pengumpulan data pada suatu latar ilmiah, dengan menggunakan metode alamiah, dan dilakukan oleh orang atau peneliti yang tertarik secara alamiah.

Lokasi penelitian ditetapkan guna memberi kemudahan bagi peneliti untuk menyusun serta mengembangkan data secara tepat dan akurat. Sesuai dengan judul yang telah ditulis dalam rancangan penelitian maka penelitian ini mengambil lokasi di Kabupaten Ketapang, tepatnya di SMP Negeri 3 Ketapang.

Yang menjadi subjek penelitian adalah peserta didik di SMP Negeri 3 Ketapang. Dalam penelitian ini yang bertindak sebagai guru adalah penulis.

Penelitian ini dilaksanakan pada semester 'Ganjil Tahun Pelajaran 2020/2021 (September s.d. November 2020) dengan memilih siswa di SMP Negeri 3 Ketapang sebagai responden. Penentuan kelas ini didasarkan atas 2 faktor yaitu; pertama, di kelas ini belum diadakan penelitian sejenis mengenai sumber belajar IPS Sejarah yang berupa film dokumenter; kedua, kebetulan kelas ini merupakan salah satu tempat mengajar peneliti.

Dengan pelaksanaan pembelajaran dikelas menggunakan Film Dokumenter sebagai sumber belajar IPS Sejarah diharapkan dalam proses 
pembelajaran akan membuka kesempatan seluasluasnya kepada peserta didik untuk ikut aktif dalam pembelajaran. Dengan demikian guru bertanggung jawab penuh dalam memantau peserta didik dalam proses belajar mengajar, maka indikator keberhasilan dengan pembelajaran dengan menggunakan film dokumenter adalah $83 \%$ peserta didik telah mencapai kriteria ketuntasan minimal (KKM) yaitu 75 sesuai dengan yang ditetapkan SMP Negeri 3 Ketapang.

\section{HASIL DAN PEMBAHASAN \\ Hasil Penelitian \\ Keefektifitasan penggunaan film dokumenter}

Penggunaan film dokumenter di SMP Negeri

3 Ketapang diberikan oleh guru sebagai salah satu sumber belajar siswa. Guru menggunakan film dokumenter sebagai salah satu sumber belajar dengan tujuan agar siswa lebih bersemangat dan tidak bosan dengan pembelajaran yang diberikan oleh guru. Guru berharap dengan dipakainya film dokumenter sebagai salah satu sumber belajar membuat pandangan siswa tentang pembelajran sejarah membosankan itu dapat berubah.

Dalam penggunaan film dokumenter ini ternyata tidak semudah yang dibayangkan, karena guru juga harus mencari film dokumenter ini dari internet ataupun youtube. Hal inilah yang perlu diberikan apresiasi lebih, karena guru mempunyai kemauan yang sangat kuat agar murid-muridnya mendapatkan sumber belajar yang baik walaupun guru tersebut harus lebih ekstra lagi dalam menyiapkan materi yang akan diajarkan. Bagaimana tidak sebelum mengajar guru juga harus menyiapkan silabus dan RPP, dan kemudian dengan memanfaatkan film dokumenter yang digunakan guru juga harus mampu membagi waktunya untuk mendownload film dokumenter tersebut dari internet.

Film dokumenter yang didownload oleh peneliti memang belum terlalu banyak yaitu antara lain ada film tentang manusia purba, tentang kedatangan VOC ke Indonesia dan film dokumenter berakhirnya orde baru dan lahirnya reformasi. Bukan dari berapa banyak jumlah film yang dmiliki oleh peneliti tapi bagaimana cara beliau mendapatkannya. Hal ini tentu harus mendapatkan apresiasi yang lebih karena semangat beliau yang begitu besar untuk memberikan suatu proses pembelajaran sejarah terbaik untuk anakanak didiknya.

Hasil yang dilihat guru selama ini menyimpulkan bahwa guru harus lebih kreatif dan mampu memberikan berbagai metode-metode menarik saat mengajar bukan hanya menggunakan sumber belajar yang menarik. Karena apabila guru hanya menggunakan film dokumenter sebagai sumber belajar tanpa disertai dengan penggunaan metode-metode lain yang menarik maka pembelajaran akan berlangsung kurang efektif. Dalam hal ini gurulah yang mempunyai peranan penting karena guru sendiri yang harusnya mampu mengembangkan minat siswa dalam belajar sejarah. Kesimpulannya adalah bukan pelajaran sejarah yang membosankan akan tetapi tergantung guru dalam menyampaikan materi yang diajarkan kepada siswanya.

\section{Sarana dan Prasarana Penunjang}

Penggunaan film dokumenter tentunya membutuhkan sarana dan prasarana penunjang yang baik agar bisa berjalan dengan efektif. Salah satu sarana dan prasarana yang sangat vital dalam penggunaan film dokumenter adalah LCD. Tanpa adanya LCD dalam ruang kelas tentu akan menghambat penggunaan film dookumenter. Di SMP Negeri 3 Ketapang sendiri disemua kelas sudah tersedia atau sudah memiliki LCD, akan tetapi ada beberapa ruang kelas yang LCD dalam kelasnya rusak. Hal ini cukup mengganggu karena apabila kelas yang LCDnya rusak akan menggunakan film dokumenter sebagai sumber belajar maka hars mencari ruangan lain yang kosong. SMP Negeri 3 Ketapang sendiri sebenarnya mempunyai laboratorium IPS yang dapat dimanfaatkan sebagi tempat belajar siswa, akan tetapi laboratorium IPS ini justru jarang diapaki oleh guru bahkan hampir tidak pernah digunakan sebagi tempat belajar siswa. Siswa hanya menggunakan ruang kelasnya saja untuk melaksanakan proses belajar mengajar.

Fasilitas yang disediakan oleh sekolah alangkah baiknya dimanfaatkan pula dengan sebaik-baiknya oleh guru dan siswa. Selain tentunya sudah menggunakan biaya banyak untuk membangunnya,

fasilitas-fasilitas yang sudah disediakan oleh sekolah tentu bertujuan agar proses pembelajaran yang berlangsung disekolah tersebut dapat berjalan semakin baik dan hasil yang dicapaipun dapat semakin baik. Seperti yang sudah disebutkan dalam kendala penggunaan film dokumenter bahwa ada ruang kelas yang LCDnya rusak, hal itu bisa diatasi dengan penggunaan laboratorium sebagai tempat pengganti ruang kelas yang LCDnya rusak.

Peneliti mengambil kesimpulan dari penelitan yang dilakukan bahwa sebenarnya SMP Negeri 3 Ketapang sendiri sudah mempunyai fasilitas yang bagus dan lengkap, ada ruang kelas yang LCDnya rusak akan tetapi itu seharusnya bisa ditutupi atau diatasi dengan adanya laboratorium. Jadi dari segi sarana dan prasarana SMP Negeri 3 Ketapang sudah memenuhi standar hanya saja dari segi pemanfaatannya saja yang masih perlu 
ditingkatkan. Karena meskipun fasilitas yang dimiliki sudah lengkap dan bagus tapi pemanfaatannya masih kurang tentu hasilnya kurang baik.

Tanggapan Guru dan Siswa dalam Penggunaan Film Dokumenter. Penggunaan film dokumenter sebagai sumber belajar dalam proses pembelajaran IPS sejarah memunculkan berbagai tanggapan dan juga pendapat dari guru maupun siswa yang terlibat didalamnya. Guru-guru sejarah yang menggunakan film dokumenter sebagai slah satu sumber belajar mengatakan bahwa penggunaan film dokumenter ini sangat bagus digunakan karena membuat siswa menjadi mendapatkan lebih banyak sumber ilmu. Akan tetapi guru juga berpendapat bahwa penggunaan film dokumenter ini dalam prakteknya tidak semudah yang dibayangkan. Disini guru tidak hanya menampilkan film dokumenter dan membiarkan siswa menonton film tersebut sampai selesai. Lebih dari itu guru harus memberikan perhatian ekstra kepada siswa, karena apabila siswa dibiarkan menonton dan guru tidak membiarkan maka materi yang tadinya ingin disampaikan oleh guru kepada siswa akan gagal.

Guru mengatakan bahwa siswa justru sering memanfaatkan pemutaran film dokumenter dengan mengobrol atau melakukan kegiatan lain yang justru dapat mengganggu proses pembelajaran. Disini guru dituntut harus benar-benar selalu memperhatikan siswa saat mereka melihat film dokumenter, karena apabila tidak diperhatikan dengan baik maka tujuan pembelajaran tidak tercapai dengan baik.

Siswa sendiri sebagian besar memberikan respon yang positif dengan digunakannya film dokumenter ini sebagai sumber belajar. Mereka mengatakan bahwa senang apabila film dokumenter digunakan sebagai salah satu sumber belajar. Film dokumenter menurut mereka membuat pikiran refresh sebelum pelajaran dimulai. Mereka mengatakan bahwa dengan penggunaan film dokumenter ini membuat pelajaran sejarah lebih menyenangkan dan tidak membosankan.

Peneliti menyimpulkan bahwa penggunaan film dokumenter mendapatkan tanggapan yang positif dari guru maupun siswa. Baik guru dan siswa mengatakan bahwa dengan digunakannya film dokumenter sebagai salah satu sumber belajar membuat pembelajaran semakin menyenangkan dan membuat pikiran refresh sebelum pelajaran dimulai. Akan tetapi ada sedikit tanggapan yang kurang baik dari guru bahwa penggunaan film dokumenter terkadang dimanfaatkan oleh siswa untuk melakukan kegiatan lain yang justru mengganggu proses pembelajaran yang sedang berlangsung.

\section{Kendala yang Dihadapi dan Upaya Mengatasinya}

Dalam setiap proses pembelajaran pasti ada kendala yang dihadapi, begitu juga pembelajaran yang memanfaatkan film dokumenter sebagai sumber belajar. Peneliti melihat kendala yang dihadapi ada dua yaitu dari segi sarana dan prasarana dan dari waktu pembelajaran.

Sarana dan prasarana di SMP Negeri 3 Ketapang memang sudah cukup lengkap, namun ada beberapa kelas yang LCD dalam ruang kelasnya rusak. Hal ini tentu sangat berpengaruh karena LCD merupakan sarana yang sangat vital dalam penggunaan film dokumenter. SMP Negeri 3 Ketapang sendiri sebenarnya mempunyai laboratorium yang dapat digunakan sebagai solusi untuk mengatasi masalah tersebut. Akan tetapi fasilitas tersebut justru tidak dimanfaatkan dengan baik untuk menutup kekurangan dari LCD yang rusak.

Peneliti disini melihat bahwa SMP Negeri 3 Ketapang dari segi sarana dan prasarana sebenarnya bukan menjadi sebuah kendala atau hambatan. Hal ini karena sebenernya sudah ada laboratorium yang dimiliki untuk menutupi kekurangan tersebut, hanya saja memang pemanfaatannya yang masih sangat kurang sehingga hal yang seharusnya bukan kendala akhirnya menjadi kendala yang cukup mengganggu.

Peneliti juga melihat ada kendala dari segi waktu, khususnya untuk kelas 8 dan kelas 9 . Hal ini karena kelas 8 dan kelas 9 hanya mempunyai waktu pelajaran $1 \times 40$ menit saja untuk setiap pertemuannya. Dengan waktu yang sangat singkat seperti itu tentu sangat kurang, karena materi pelajaran sejarah cukup banyak. Hal ini membuat guru menjelaskan materi dengan cara yang cepat agar materi dapat disampaikan semua kepada siswa, akan tetapi justru siswa kurang paham dengan materi yang diajarkan oleh guru karena cara menjelaskan materi terlalu cepat. Hal ini sangat ironis karena dengan materi yang banyak akan tetapi waktu yang diberikan hanya sedikit.

Kendala-kendala yang dihadapi itu pasti tetap ada upaya untuk mengatasinya. Dari kendala yang dihadapi pertama yaitu sarana LCD pada beberapa kelas yang rusak bisa diatasi dengan menggunakan ruang lain yang tidak digunakan. Dari peneliti sendiri melihat bahwa hal itu sebenarnya mudah diatasi apabila guru mau lebih memanfaatka saranasarana lain yang disediakan oleh sekolah seperti laboratorium IPS. 
Kendala berikutnya adalah waktu, khususnya untuk kelas 8 dan kelas 9 , upaya yang dilakukan adalah menyingkat materi yang disampaikan yaitu dengan cara lebih meringkas materi dan diambil lebih keintinya saja. Selain itu dengan menggunakan metode pembelajaran lain yang dapat menyinkat waktu guru dalam menyampaikan materi. Contohnya dengan menggunakan kuis, disitu siswa dapat menyerap materi yang diberikan oleh guru sebelum guru menjelaskan materi yang diajarkan. Hal ini karena sebelum pelajaran dimulai siswa dituntut untuk mempelajari pelajaran yang akan diajarkan oleh guru. Hal-hal seperti itulah yang selalu dilakukan oleh guru agar siswa mau belajar lebih tekun sebelum guru menjelaskan materi.

\section{Pembahasan}

\section{Keefektifitasan penggunaan film dokumenter sebagai sarana siswa untuk mempelajari Sejarah}

Film dokumenter adalah film yang mendokumentasikan kenyataan. Istilah "dokumenter" pertama digunakan dalam resensi film Moana (1926) oleh Robert Flaherty, ditulis oleh The Moviegoer, nama samaran John Grierson, di New York Sun pada tanggal 8 Februari 1926.

Film dokumenter sendiri sering digunakan dalam dunia pendidikan. Hal ini dikarenakan film dokumenter adalah sebuah film yang menceritakan sebuah kenyataan. Film dokumenter yang sering dipakai antara lain adalah film yang menceritakan sejarah. Dalam penggunaan film dokumenter bagi siswa akan lebih semangat dan juga merasa direfresh terlebih dahulu sebelum mereka menerima pembelajaran. Bagi guru, mempermudah dalam

menjelaskan materi karena sebelum pelajaran dimulai siswa sudah terlebih dahulu ditarik daya pikirnya dengan menggunakan film dokumenter. Penggunaan film dokumenter sendiri memang bertujuan agar sebelum siswa mendapat penjelasan materi oleh guru mereka sudah tergugah daya pikirnya.

SMP Negeri 3 Ketapang adalah sekolah yang memanfaatkan film dokumenter sebagai salah satu sumber belajar, karena film dokumenter sendiri dianggap bisa membuat siswa menjadi lebih semangat belajar. Akan tetapi dalam pemanfaatan film dokumenter ini guru juga harus pintar-pintar dalam penggunannya karena bisa jadi saat film dokumenter ini diputar siswa justru tidak memperhatikan dengan baik.

Dalam menunjang pembelajaran dengan menggunakan film dokumenter banyak hal yang sudah dilakukan oleh sekolah, antara lain disetiap kelas sudah tersedia LCD SMP Negeri 3 Ketapang juga mempunyai laboratorium IPS yang bisa digunakan untuk proses pembelajaran sejarah.

Dari pengamatan peneliti bahwa penggunaan film dokumenter di SMP Negeri 3 Ketapang belum maksimal dikarenakan ada beberapa kelas yang LCDnya rusak, selain itu pemanfaatan laboratorium IPS juga masih kurang. Selain itu jam pelajaran untuk kelas 8 dan kelas 9 yang hanya 1x40 menit membuat penggunaan film dokumenter kurang maksimal.

Dalam penggunaan film dokumenter, guru dan siswa harus bisa saling melengkapi dan bekerja sama dengan baik, karena apabila tidak berkolaborasi dengan baik tujuan pembelajaran tidak tercapai dengan baik. Disisi pengajar, guru harus mampu memanfaatkan penggunaan film dokumenter dengan baik karena apabila mampu memanfaatkan dengan baik maka kerja guru dalam menyampaikan materi kepada anak didiknya akan lebih mudah dan baik. Disisi murid, siswa juga harus bisa menjadi penikmat yang baik, karena dengan memperhatikan dengan baik mereka akan mudah dalam menyerap materi yang nantinya akan disampaikan oleh guru. Selain itu penggunaan film dokumenter juga akan menghilangkan meanset mereka yang berfikir bahwa sejarah hanya disampaikan dengan ceramah oleh guru mereka.

Dari pengamatan yang peneliti lakukan saat melakukan pembelajaran di kelas siswa tidak suka menerima materi hanya dengan ceramah tapi mereka menginginkan metode-metode lain dan terobosan-terobosan lain yang membuat mereka tidak jenuh dan bosan dalam belajar sejarah. Dengan film dokumenter yang diputarkan pada awl pembelajaran membuat mereka antusias dan lebih semangat dalam mengikuti pelajaran. Akan tetapi guru juga harus mampu mengkondisikan kelas pada saat film dokumenter diputar, karena apabila tidak dikondisikan dengan baik maka siswa tidak fokus dalam memperhatikan film, hal inilah yang dapat berdampak pada penyampaian materi yang kurang baik nantinya.

Jadi, penggunaan film dokumenter di SMP Negeri 3 Ketapang dapat bermanfaat dengan baik asalkan penggunaannya bisa dilakukan dengan efektif dan efisien. Karena penggunaan film dokumenter yang tidak efektif justru akan membuat kondisi pembelajaran tidak berjalan dengan baik dan justru hasil yang diharapkan tidak akan tercapai.

\section{Kondisi Sarana dan Prasarana dalam Menunjang dan Mendukung Penggunaan Film Dokumenter dalam Pembelajaran Sejarah}

Penggunaan film documenter diperlukan komponen-komponen lain yang dapat mendukung kelancaran pemanfaatannya. Karena pemutaran 
film dokumenter sendiri membutuhkan media LCD yang merupakan komponen paling penting.

SMP Negeri 3 Ketapang sendiri merupakan sekolah yang mempunyai kualitas bagus, karena semua ruangan kelas dan laboratorium memeliki LCD. Selain itu jaringan internet di SMP Negeri 3 Ketapang juga bagus. Hal ini membuat siswa lebih mudah dalam mengakses internet untuk kepentingan pembelajaran. Kemudian di SMP Negeri 3 Ketapang juga tersedia laboratorium IPS yang diperuntukan guna kepentingan siswa dalam mempelajari mata pelajaran Sejarah, Geografi dan Ekonomi. Seperti wawancara dengan salah satu siswa kelas 8 bernama Antoni sebagai berikut:

-ya disini tersedia laboratorium yang digunakan untuk siswa, akan tetapi jarang dipakai, pelajaran seringnya hanya didalam kelas jarang dilakukan dilaboratorium (wawancara Antoni, tanggal 26/09/2019) Begitu juga dengan Yolanda salah satu siswa kelas 8 yang mengatakan bahwa kurangnya pemanfaatan laboratorium IPS sebagai salah satu fasilitas yang bisa digunakan sebagai tempat pemutaran film dokumenter. Dari hasil peneltian dapat ditangkap bahwa sarana dan prasarana yang dimilik oleh SMP Negeri 3 Ketapang sebenernya sudah bagus hanya pemanfaatannya yang masih kurang maksimal.

Pada penggunaan film dokumenter sendiri perlu kondisi ruang kelas yang baik dan nyaman, karena itu akan berpengaruh pada konsentrasi siswa dalam menikmati film dokumenter. Dari hasil peneitian sendiri peneliti melihat kondisi ruang kelas di SMP Negeri 3 Ketapang sudah baik dan nyaman guna menjalankan pemebelajaran Sejarah. Tata ruang kelas juga disusun oleh wali kelas beserta siswa, hal inilah yang membuat siswa nyaman dan senang berada didalam kelas karena mereka sendiri yang menata dan menentukan suasana kelas mereka sendiri. Akan tetapi, hal ini perlu pengamatan dan juga pengawasan yang lebih dari wali kelas, karena bagaimanapun wali kelaslah yang bertanggung jawab akan kelas tersebut agar sesuai dengan ketentuan.

Selain sarana-sarana tersebut, disetiap kelas juga sedemikian rupa ditata agar siswa nyaman, walaupun letak tata kursi dan meja yang masih biasa, namun disitu telah disediakan gambar-gabar pahlawan dan juga poster yang ditempelkan di dinding. Selain itu dibeberapa kelas juga tersedia peta yang bisa dimanfaatkan dalam proses pembelajaran.

Dari wawancara dan pengamatan yang dilakukan oleh peneliti, media-media lain juga sering digunakan sebagai contoh, seperti gambar pahlawan, jadinya siswa bisa secara langsung mengetahui wajah pahlawan yang sedang dijelaskan, selain gambar pahlawan gambar- gambar lain juga sering diperlihatkan kepada murid agar apa yang dijelaskan oleh guru tidak hanya menjadi angan-angan oleh siswa.

Dalam pembelajaran sejarah sarana dan prasaran sudah cukup lengkap dan terpenuhi, hanya ada beberapa saja yang masih kurang. Akan tetapi menurut guru sejarah yang peneliti wawancara, semua itu sudah cukup guna menunjang pembelajaran sejarah bisa berjalan dengan baik.

\section{Tanggapan Guru dan Siswa dalam Penggunaan Film Dokumenter}

Film dokumenter adalah film yang mendokumentasikan kenyataan, oleh karena itulah film dokumenter bisa dijadikan sebagai salah salah satu sumber dalam pembelajaran sejarah. Sejarah sendiri adalah mata pelajaran yang mempelajari kejadian dimasa lalu atau masa lampau yang kebenarannya harus bisa diuji. Hal inilah yang membuat SMP Negeri 3 Ketapang juga menggunakan film dokumenter sebagai salah satu sumber belajar, salah satunya dalam pembelajaran sejarah.

Dari wawancara yang dilakukan oleh peneliti, guru di SMP Negeri 3 Ketapang sudah paham betul arti dari film dokumenter dan bagaimana kegunaannya dapat digunakan sebagai salah satu sumber belajar. Karena selain fungsinya yang memang sangat cocok digunakan dalam pembelajaran sejarah, film dokumenter sendiri dapat digunakan guru sebagai daya tarik agarsiswa tidak bosan dan jenuh terhdap pembelajaran sejarah. Karena selain dengan menerapkan metodemetode pengajaran yang inovatif dan guru yang kreatif diperlukan juga sumber belajar yang menarik dan membuat siswa tertarik.

Dalam penggunaan film dokumenter guru mengungkapkan bahwa siswa semakin tertarik dan suka dengan pembelajaran sejarah, akan tetapi bukan berarti semua siswa suka dan memanfaatkan dengan baik penggunaan film dokumenter yang dilakukan oleh guru. Ada beberapa siswa dalam pembelajaran yang menurut guru sering memanfaatkannya justru untuk mengobrol dan sibuk sendiri, dan akhirnya tidak dapat menangkap dengan baik materi yang ada dalm film dokumenter. Hal inilah yang dikhawatirkan oleh guru, karena dengan waktu yang terbatas belum tentu materi akan dapat terselesaikan dengan baik dari sisnilah guru harus pintar-pintar memanajemen waktu.

Dari wawancara yang peneliti lakukan, hal yang tersebut diatas tidak menjadi hambatan dan halangan guru untuk menggunakan film dokumenter, karena menurut pendapat guru yang bersangkutan dalam setiap pembelajaran pasti ada kendala yang dihadapi dan justru itulah yang 
menjadi tantangan bagi guru tersebut apakah mampu menghadapi dan melewati hambatan dan tantangan terebut. Guru tetap memberikan tanggapan positif terhadap minat siswa dalam penggunaan film dokumenter walaupun ada beberapa tanggapan negatif yang peneliti tangkap dari hasil wawancara yang dilakukan. Seperti kutipan dari salah satu guru berikut ini:

Dalam proses pembelajaran sejarah semua siswa dapat mengikuti dengan baik. Walaupun memang terkadang dalam pembelajaran yang menggunakan film dokumenter ada beberapa siswa yang kurang mempehatikan dan justru memanfaatkannya untuk mengobrol dan sibuk sendiri,tapi semua itu masih bisa diatasi asalkan guru menggunakan metode yang benarl (Wawancara Siti Musliha, guru sejarah, Tanggal 26/09/2019).

Dari hasil penelitian dan pengamatan yang peneliti lakukan selama kegiatan pembelajaran juga dapat dilihat siswa sangat tertarik saat peneliti menggunakan film dokumenter saat pelajaran sejarah. Mereka lebih ceria dan gembira saat diputarkan film dokumenter sebelum pelajaran dimulai. Hal inipun dibenarkan oleh guru sejarah di SMP Negeri 3 Ketapang. Peneliti sangat mengapresiasi dengan baik minat siswa dalam penggunaan film dokumenter. Bahkan karena sangat tertariknya siswa dengan film dokumenter, ada beberapa siswa yang meminta film dokumenter yang diputar kepada peneliti.

\section{Kendala-kendala yang Dihadapi dalam Penggunaan Film Dokumenter dan Upaya Untuk Mengatasinya}

Pelaksanaan pembelajaran sejarah dengan menggunakan film dokumenter tidak selalu berjalan dengan lancar dan sesuai yang diharapkan. Dalam pelaksanaannya pasti akan muncul kendalakendala. Bagi sekolah yang sarana dan prasarananya belum memadai dan lengkap, pastilah akan menemui kendala dalam penggunaan film dokumenter. Hasil penelitian yang telah dilakukan di SMP Negeri 3 Ketapang, peneliti menemukan beberapa kendala dalam penggunaan film dokumenter sebagai salah satu sumber belajar pada pembelajaran di sekolah ini.

Peneliti ingin membahas kendala itu secara umum terlebih dahulu yang dihadapi oleh SMP Negeri 3 Ketapang dalam penggunaan film dokumenter sebagai salah satu sumber belajar dalam pembelajaran sejarah. Kendala pertama secara umum yang dihadapi oleh SMP Negeri 3 Ketapang dalam penggunaan film dokumenter adalah pemanfaatannya yang harus benar-benar diamati oleh guru dalam pelaksanaan pembelajaran sejarah, karena apabila penggunaan film dokumenter tidak diawasi dan dimanfaatkan dengan benar justru akan membuat pembelajaran tidak berjalan dengan baik.

Kendala yang kedua masalah kondisi ruang kelas karena ada beberapa kelas yang sarana dan prasarananya rusak, apalagi sarana inilah yang sangat vital dalam pemanfaatan film dokumenter seperti LCD, namun kendala-kendala seperti ini sudah bisa diatasi dan dapat diupayakan agar tidak mengganggu proses pembelajaran.

Pada pembelajaran sejarah khususnya ada kendala-kendala yang menghambat diterapkannya penggunaaan film dokumenter, kendala yang utama adalah waktu. Dalam pembelajaran sejarah di SMP waktu pelajaran adalah 1 x40 menit saja untuk setiap satu kali pertemuan di kelas 8 dan kelas 9, hal inilah yang kadang membuat penggunaan waktu kurang efektif, yang tadinya tujuan penggunaaan film dokumenter ini adalah untuk menyingkat waktu penyampaian materi oleh guru justru malah membuat materi tidak tersampaikan semua dengan baik karena keterbatasan waktu. Upaya yang harus dilakukan guru adalah pemadatan materi agar materi dapat tersampaikan semua dengan baik dan efektif.

Kondisi siswa juga salah satu faktor penting dalam penggunaan film dokumenter sebagai salah satu sumber belajar siswa. Karena apabila di amati dengan seksama kadang penggunaan film dokumenter pada saat pelajaran sejarah dimanfaatkan oleh siswa untuk mengobrol atau bermain. Memang tidak semua siswa melakukan hal ini, namun apabila ini dibiarkan terus menerus akhirnya akan membuat siswa lain terganggu dan fokusnya akan terpecah. Seperti kutipan wawancara berikut :

- ya kadang kita merhatiin kalau kita suka filmnya, kalau filmnya jelek ya bosen ngeliatnya ! (Wawancara, Rudi dan Aulia, Tanggal 26/09/2019).

Kondisi inilah yang harus benar-benar diperhatikan oleh guru, sangat tidak menguntungkan apabila dalam pembelajaran yang sudah dirancang dengan baik oleh guru dan dengan memanfaatkan media yang baik pula justru tidak mendapatkan hasil yang sesuai dengan apa yang diinginkan.

Guru harus menyiasati bagaimana agar siswa tertarik dengan film yang di putar. Selain itu manajemen waktu juga harus diperhatikan, karena dengan waktu yang sangat minim guru harus membaginya dengan baik untuk pemutaran film dan penyampaian materi kembali oleh guru agar film dokumenter yang diputar dapat ditangkap dengan baik maknanya oleh siswa.

Dari hasil pengamatan yang peneliti lakukan, ada beberapa guru yang masih kurang dalam 
penggunaan metode-metode lain dalam proses pembelajaran. Kebanyakan guru masih menggunakan metode ceramah yang didominasi oleh guru dan siswa hanya pasif mendengarkan guru menyampaikan materi didepan. Setelah materi selesai dijelaskan siswa disuruh mengerjakan lembar kerja siswa. Guru kurang memberikan ruang dan kurang memancing siswa agar siswa aktif dan lebih kreatif dalam proses pembelajaran.

Dalam penggunaan film dokumenter sebagai salah satu sumber belajar juga perlu diimbangi dengan penggunaan metode-metode lain yang dapat mensukseskannya. Karena dengan metodemetode yang menarik membuat siswa semangat dan tertarik dalam pembelajaran sejarah. Seperti sudah dijelaskan tadi bahwa tidak semua siswa suka dan tertarik saat film dokumenter diputar, oleh karena itulah sudah menjadi tugas guru agar siswa dapat tertarik dan suka tanpa terkecuali. Jadi siswa akan merasa penasaran dengan film yang akan diputar dan memperhatikan dari awal hingga akhir film dokumenter itu diputar.

\section{SIMPULAN DAN SARAN Simpulan}

Dari hasil penelitian yang telah dilakukan oleh peneliti, maka disimpulkan bahwa: (1) harus ada kerjasama yang baik antara guru dan siswa agar tujuan dari penggunaan film dokumenter ini dapat tercapai. Guru harus pintar-pintar dalam penggunaannya dan siswa harus mempunyai minat yang tinggi. (2) Setiap kelas sudah mempunyai LCD meskipun ada beberapa kelas yang LCDnya rusak. SMP Negeri 3 Ketapang juga mempunyai laboratorium-laboratorium yang fasilitasnya sudah cukup lengkap, antara lain laboratorium IPS, laboratorium IPA, dan laboratorium TIK. Selain itu koneksi internet disana juga sangat bagus, ini tentunya sangat baik karena dapat digunakan untuk menunjang pembelajaran di SMP Negeri 3 Ketapang. (4) Guru memberi tanggapan positif dan baik terhadap minat siswa dalam penggunaan film dokumenter sebagai salah satu sumber belajar sejarah.(4) kendala yang timbul dalam penggunaan film dokumenter sebagai salah satu sumber belajar dalam pembelajaran sejarah.

\section{Saran}

Bagi pihak sekolah: (1) Lebih memperhatikan sarana dan prasarana yang belum tersedia ataupun rusak di SMP Negeri 3 Ketapang, karena kekurangan dalam sarana dan media pembelajaran sangat berpengaruh dalam proses pembelajaran, dengan ditunjang sarana dan prasarana yang baik dan bagus maka penggunaan film dokumenter sebagai salah satu sumber belajar akan tercapai tujuannya dengan baik. (2) Siswa harus lebih tertarik dan cinta terhadap sejarah dengan penggunaan film dokumenter, karena dengan penggunaan film dokumenter sebagai salah satu sumber belajar membuat siswa menjadi tidak bosan dan jenuh dan ounya lebih banyak referensi. Siswa juga diharapkan semakin suka menggunakan film dokumenter sebagai sumber belajar mereka selain membaca buku dan dari internet.

\section{DAFTAR RUJUKAN}

Agung S., Leo dkk. 2013. Perencanaan Pembelajaran Sejarah. Yogyakarta: Ombak

Aman. 2011. Model Evaluasi Pembelajaran Sejarah. Yogyakarta: Ombak

Isjoni. 2007. Pembelajaran Sejarah. Bandung : Alfabeta.

Kochhar, S.K. 2008. Pembelajaran Sejarah. Terjemahan Purwanta dan Yovita hardiati. Jakarta : PT Grasindo.

Moleong, Lexy.2010. Metode Penelitian Kualitatif. Jakarta : UI Press.

Munib, Ahmad. 2010. Pengantar Ilmu Pendidikan. Semarang: UNNES Pres

Sugiyono. 2009. Metode Penelitian Kuantitatif, Kualitatif, dan $R \& D$. Bandung : Alfabeta.

Widya, I Gde. 1989. Dasar-dasar Pengembangan Strategi serta Metode Pengajaran Sejarah. Jakarta : Depdikbud. 